\title{
Musharraf under modsatrettet pres
}

Mogens Fenger

Når den pakistanske præsidents manøvrer forekommer uoverskuelige, skyldes det ikke mindst det komplicerede magtspil, der præger både det politiske, det religiøse og det økonomiske liv i landet

Under sit besøg i Islamabad i juni i år sagde den amerikanske udenrigsminister Condoleeza Rice, at Pakistans præsident Musharraf er en nær allieret af USA i krigen mod terror, men han bør gøre mere for at lukke sin grænse mod Afghanistan for talebaner og al-Qaedaer, der fører krig for at destabilisere en anden nær forbundsfælle af USA, præsident Karzai i Kabul. Det kræver flere og flere internationale tropper i Afghanistan at holde Karzai ved magten, og når oprørerne bliver trængt, kan de bare smutte over grænsen til Pakistan. Det ønsker USA bragt til ophør.

Tilsvarende har regeringen i Delhi, en tredje god ven af USA, gentagne gange sagt, at Pakistan trods forsikringer om det modsatte ikke gør nok for at hindre islamiske krigere $\mathrm{i}$ at krydse våbenstilstandslinjen til indisk Kashmir, hvor de angriber indiske sikkerhedsstyrker og retter terroranslag mod civile mål dér. Også bomberne i Mumbai 17. juli 2006, der dræbte 182 og kvæstede over 500, har inderne rutinemæssigt sat i forbindelse med militante grupper med tilholdssted i Pakistan, dog blev også islamister fra Indien nævnt som mulige gerningsmænd.

Pakistanerne har svaret ved at pege på, at deres hær igen i dette forår med store styrker gik ind $i$ grænseegnene mod Afghanistan for at inddæmme og eliminere talebaner og al-Qaedaer. Videre siger de, at de efter 11. setpember 2001 har slået ned på islamistiske terrororganisationer med forbud og fængs- 
linger og ryddet deres træningslejre i Pakistan. Et ikke ubetydeligt antal prominente al-Qaedaer er pågrebet på pakistansk område, og efter den blodige terror i London 7. juli 2005 har regeringen udvist fremmede studenter ved de koranskoler, der hævdes at være udklækningssteder for talebankrigere og islamister af europæisk oprindelse.

Det var pakistanske efterretningstips til britiske kolleger, der i dagene omkring 10. juli 2006 kan have hindret et større antal fly i at være blevet sprængt efter at være lettet fra Heathrow. Og 30. september dokumenterede Musharrafs militær igen sin samarbejdsvilje ved at lade kamphelikoptere pulverisere en koranskole ved Khar i Bajaur med den begrundelse, at den uddannede sine studerende også i våbenbrug.

\section{Rider på to heste}

Men svaret vil næppe få kritikken af Pakistan til at forstumme.

I områderne bag den afghanske grænse har hæren muligvis nok ekspederet nogle internationale al-Qaedatyper, men mange talebaner har fået lov at smutte, fordi de nyder lokal sympati og får beskyttelse af grænselandets stammeledere, som regeringen ikke har råd til for alvor at lægge sig ud med, siger kritikerne.

Ligeledes er de islamiske grupper, der især opererer i Kashmir, godt nok blevet forbudt i Pakistan, men det har ikke hindret dem i at omgruppere og genopstå under ny navne, og så skrues der ned og op for aktiviteten, men ophørt er den ikke, siger Delhi. Musharraf insisterer også på, at indisk Kashmir med den hovedsageligt muslimske befolkning er uretmæssigt besat, og at kampene dér er befrielseskrig mod en besættelsesmagt.

Musharraf rider åbenbart to heste, og der er to opfattelser af hvorfor.

Den ene er, at han er fanget i et dilemma. Han kan ikke opgive sin alliance med USA og sin forståelse med Indien. USA truede med at bombe Pakistan sønder og sammen, hvis han ikke gik med i krigen mod terror efter 11. september 2001, sagde han i amerikansk fjernsyn i september i år, og nytår 2001-02 stod Pakistan og Indien på randen af en krig, hvor atombomberne var armeret, og siden har begge parter set fordelen ved at undgå en gentagelse. Men Musharraf kan heller ikke lægge sig alvorligt ud med den religiøse og nationalistiske opinion i sit land, og den rækker langt videre end til de politisk organiserede islamister og fundamentalister. Den formodes at have tilhængere højt op i militæret og bureaukratiet, og uden deres støtte kan ingen regering i Pakistan blive siddende.

Derfor bliver landets politik en balance mellem de uforenelige hensyn til det internationale samfund og den hjemlige religiøse opinion. 
Det er der måske en vis forståelse for både i USA og Indien, siden de ikke lægger større pres på Pakistan, end de gør.

Iagttagere forklarer det gerne med, at man i både Washington og Delhi frygter et kaotisk, talebaniseret, uberegneligt Pakistan, hvis Musharraf væltes, og man ser nødig det pakistanske atomarsenal i forkerte hænder.

Den anden udlægning er, at der slet ikke er noget dilemma, for i virkeligheden samarbejder Musharraf med islamisterne. Den tilsyneladende modsætning er blot en vildledende rollefordeling: Islamisterne ønsker talebanherredømme i Afghanistan, og Pakistans regering har også altid søgt dominerende indflydelse i Kabul, ligesom Indiens britiske koloniherrer gjorde før 1947. Talebanherredømmet i Afghanistan fra 1995/96 og frem til 2001 skyldtes ikke mindst støtte fra Pakistans hær, efterretningsvæsen og handelsinteresser.

Rollefordelingen går efter denne teori ud på, at islamisterne appellerer til befolkningen ved at protestere mod Musharrafs proamerikanske udenrigspolitik, og når USA, Vesten og Indien kræver Pakistans grænser lukket for mujahidiner og talebaner fra Afghanistan, kan Musharraf henvise til islamisternes fremgang i landet, hvorpå de udenlandske magter opgiver at presse ham for hårdt, fordi de frygter hans fald og påfølgende talebanisering af Pakistan.

\section{Mellem diktatur og demokrati}

Condoleeza Rice sagde også noget andet i juni: Det kommende valg i Pakistan 2007 bør være gennemskueligt. Valg foregår altid åbent her i landet, og vi tillader ingen indblanding udefra, replicerede informationsminister Tariq Azim Khan, et svar, som vakte en vis moro, for $\mathrm{Pa}$ kistan har jo stået under militærstyre siden general Musharrafs kup november 1999, der fældede en regering med flertal i parlamentet.

Men der har været valg i Musharrafs tid. April 2002 lod han sig kåre til præsident ved en folkeafstemning, og november samme år blev der afholdt valg til både det føderale parlament i Islamabad og til parlamenterne i Pakistans fem delstater. Valghandlingerne blev kritiseret for fusk og svindel, så legitimiteten kan betvivles, men Musharraf fik et flertal i Nationalforsamlingen bag sin premierminister, og - militærstyre eller ej - ingen regering kan undvære en vis politisk støtte fra samfundets vigtigere grupper og institutioner.

Det er nærliggende at fokusere på modsætningen mellem diktatur og demokrati, men man kan også spørge på en anden måde: Hvem er inde, og hvem er ude, når goderne fordeles og beslutningerne træffes?

Her må man skelne mellem magtfaktorer, der ikke er på valg, især militæret og bureaukratiet, og andre, hvis styrke afhænger af vælgernes til- 
slutning, dvs. de politiske partier.

Militæret har altid haft stor politisk indflydelse i Pakistan, således når dets chefer kuppede sig til magten, men også under civilt styre hvor generalerne givetvis har sat en ramme, politikerne måtte færdes indenfor.

Vigtigere for Musharrafs politiske balancegang er det, om han kontrollerer alle dele af militæret, eller om oppositionelle elementer her får mulighed for at fremkalde hans fald eller kan tvinge ham til at ændre politik.

For det første skal officerskorpset have ændret sig gennem snart mange år, islamiseringen skal være krøbet opad i graderne - december 2003 var der to attentatforsøg mod Musharraf, og fire måneder efter sagde han, at lavere officerer stod bag, men i de højere echeloner var der ingen vaklen.

Spørgsmålet er ikke, om Musharraf bliver dræbt, men om hvornår det sker, sagde iagttagere dengang, som troede på en konflikt mellem den vestligt tænkende præsident og islamisterne, men præsidenten er stadig i live.

For det andet skal forskellige dele af militæret og især dets efterretningstjeneste, ISI, have ført sin egen udenrigspolitik over for Taleban i Afghanistan, og dens chef gik af, da Musharraf gik med USA mod Mullah Omar og Osama ben Laden i Afghanistan efter 11. september 2001. Så måske ved militærets ene hånd ikke, hvad den anden gør, eller også fører militær og regering bevidst politik med flere hænder.

Hvad angår de politiske partier er der de verdslige, og der er de religiøse. Og der er dem, der støtter Musharrafs regering og dem, der ikke gør.

Alliancen bag regeringen i Nationalforsamlingen består for det første af en del af Pakistan Muslim League (PML), et verdsligt parti, der også havde regeringsmagt før kuppet 1999. Men kort efter splittedes det for ikke at blive trukket med ned af sin tidligere leder, premierminister Nawaz Sharif, der blev sendt i eksil efter dom for flykapring og korruption, og hovedfløjen støtter nu Musharraf.

For det andet samarbejder regeringen med alliancen af seks religiøse partier Muttahida Majles-i-Amal (MMA). Et af dem er Jamiat-ul-Ulema-e-Islam (JUI), som står bag hovedparten af alle Pakistans taleban-producerende religiøse skoler. Også JUI har været udsat for spaltninger. Trods samarbejdet er de religiøse partiers holdning til Musharraf ambivalent, for de er også med til at mobilisere folk mod hans vestvendte udenrigspolitik og hans lejlighedsvise undsigelse af talebanerne.

Oppositionspartierne samledes i ARD (Alliance for the Restauration of Democracy), hvor det vigtigste er $P a$ kistan People's Party (PPP), hvis egentlige leder er tidligere premierminister Benazir Bhutto, som nu er i 
eksil efter at være blevet korruptionssigtet i Pakistan. Også PPP har haft sine splittelser.

Partispaltninger er næsten et grundvilkår. Det skyldes organisationsformen, det skyldes måden at generere, mobilisere og kanalisere politisk støtte på, det skyldes politikernes rivalisering og deres behov for at bringe sig i position i forhold til magten. Der er dog partier, der fungerer anderledes, især kan nævnes Jamaat-i-Islami, et religiøst parti med effektiv topstyring og centraliseret opbygning.

Men partiernes måde at fungere på i almindelighed har stor betydning for general og præsident Musharrafs balancegang i Pakistans politiske system, og det har betydning for de skiftende alliancer mellem militær og partier, der giver regimet om ikke legitimitet, så dog hidtil tilstrækkelig politisk opbakning.

\section{Regional og religiøs modsætning}

Den alvorligste udfordring til Pakistans autoriteter er måske dog de voldelige, undertiden næsten borgerkrigsagtige konflikter, som gennem tiden er blusset op med mellemrum. Her gælder det regeringens evne til at sørge for sikkerhed og orden og holde landet sammen, helt centrale opgaver for enhver statsmagt, forudsætningen for dens autoritet indadtil og udadtil.

Problematisk kan det blive, hvis regeringen i stedet for at handle upartisk og hævet over konflikterne selv fremkalder dem eller bliver del af dem.

Blandt disse stridigheder skelnes der gerne mellem to typer, etniske og religiøse.

Pakistan består af fem provinser med indre selvstyre og i princippet befolkninger med hver sit sproglige, kulturelle og etniske særpræg - der er punjabier, sindhier, pashtuner, baluchier foruden mindre grupper uden egen provins som $\mathrm{fx}$ mohajirer, som egentlig er udvandret fra Indien ved Subkontinentets deling 1947, og hvis modersmål er urdu. Urdu er også fællessprog i Pakistan, men de andre folkegrupper har tillige deres egne modersmål.

Mellem disse grupper har der været en vis konkurrence om at påvirke de føderale myndigheder til egen fordel, eller måske snarere om at hindre rivalerne $i$ at løbe med alle fordelene, alle embederne, alle regeringskontrakterne, alle markedsandelene, al indflydelsen.

Især har de mindre delstater og deres befolkning haft et godt øje til punjabierne, som er den talrigeste gruppe.

Men hele dette spil bliver mere indviklet af, at alle disse folkegrupper ikke kun lever og arbejder i deres egen provins, men er blandet op mellem hinanden overalt. Sindhierne frygtede i 1980'erne at komme i mindretal i deres egen provins, pashtunerne dominerede transporten i hele landet, punjabierne sad 
på administration og militær, sagde man, mohajirerne krævede deres andel af det hele, baluchierne syntes, de selv fik for lidt og de andre for meget ud af naturressourcerne i Baluchistan. Så grupperne organiserede sig politisk i partier, der snart også oprettede militser og begyndte at slås med hinanden og med ordensmagten.

Fra midten af 1980'erne og op gennem 1990'erne gik det især hidsigt til i Karachi med den store havn, den store handel og det lukrative smugleri. Flere gange blev der erklæret undtagelsestilstand, en tid kom hele provinsen under militæradministration, og regeringens modstandere hævdede, at den selv havde aktier i modsætningerne og misbrugte situationen til at gøre op med sine modstandere under påskud af at genoprette sikkerhed og orden. Siden er modsætningerne i provinsen Sind og i Karachi taget af.

Til gengæld er de inden for de sidste to år blusset voldsomt op $\mathrm{i}$ Baluchistan i forbindelse med den forøgede internationale efterspørgsel efter olie og gas og spørgsmålet om placeringen af rørledninger. Den 27. august 2006 likviderede den pakistanske regering den i øvrigt politisk konservative leder af provinsens selvstændighedsbevægelse, nawaben af Bugti, sammen med hele inderkredsen af hans klan, og situationen anses nu for ude af kontrol.

Dette er åbenlyst konflikter om $\varnothing$ konomiske interesser og strid om godernes fordeling - til forskel fra kontroverser om religionens indflydelse i samfundet.

\section{Religiøse konflikter}

Modsætninger mellem religiøst definerede grupper i Pakistan har der heller ikke været mangel på, i deres kerne en strid om den rette udlægning af islam,

Sunnimuslimske aktivister har i snart 30 år med jævne mellemrum med morderiske konsekvenser angrebet shiamuslimer under bøn i deres moskeer eller under deres rituelle processioner. Shiamuslimerne har ind imellem gjort gengæld med lige så blodige resultater. Shiiterne er en minoritet i Pakistan af uafklaret størrelse, og deres ledere har organiseret sig politisk i et parti (Tehrik-e-Nefaz Jafriah) til varetagelse af deres interesser og beskyttelse af deres medlemmer.

Forskellene mellem sunniter og shiiter er af meget gammel dato, men i Pakistan blev det til akut modsætning efter oprettelsen af ayatollah Khomeinys præstestyre i Teheran 1979, som gav shiiterne vind $i$ sejlene. Især Saudi-Arabien søgte samtidig at inddæmme Irans indflydelse ved at støtte de mere radikale sunnitiske bevægelser med religiøs og økonomisk oprustning, og samme år begyndte den tids pakistanske militærstyre under general Zia ulHaq (1977-88) at islamisere landet, men på en måde der var mod shii- 
ternes tolkning af den religiøse lov.

I disse år blev frøene sået til en række af nutidens konflikter, der nok skyldes religion, men også drejer sig om magtfordeling og indflydelse på samfundets love.

Men også mellem sunnimuslimerne indbyrdes er der rituelle, teologiske og juridiske forskelle, der fører til åben strid. Her går skellet især mellem traditionalister og moderne islamister. Traditionalisterne ærer skikke og institutioner, der er vokset frem efter Profetens tid, islamisterne går ind for en renset islam, der udelukkende bygger på Koranen og Profetens normative eksempel (sunna). Traditionalisterne accepterer den skik, at de troende søger hjælp og trøst hos afdøde religiøse stormænd med særlig kontakt til Allah ved deres grav (mazar), islamisterne anser denne gravkult for afgudsdyrkelse (shirk). Men til de store grave kommer hundredtusinder, gravenes forvaltere kan have en enorm autoritet over bredere eller snævrere kredse af tilhængere (murider), og selv om gravenes tidligere jordbesiddelser (waqf) er blevet nationaliseret, er de stadig magtfaktorer i samfundet, og islamisterne vil dem til livs.

Traditionalisterne har deres religiøse skoler, som kaldes Barelvi efter en moderskole i Indien, og deres ledere kredser om et politisk parti, Jamiat-ul-ulema-i-Pakistan (JUP), mens en mere islamistisk retning kaldes Deobandi, ligeledes efter en moderskole i Indien, dens parti er Jamiat-ul-ulema-i-Islam (JUI), og det er dens omfattende netværk af koranskoler, der har udklækket et stort antal talebaner.

Begge disse to ulema-partier - ulema er islams skriftlærde - har haft samme tendens til at splittes som de førnævnte verdslige partier. Dette er aldrig sket for et tredje religiøst parti, Jamaat-i-Islami, som netop i kraft af sin strammere organisation har større indflydelse, end dets medlemstal og stemmer ved valgene kan begrunde.

Det er altså disse partier, som kalder folk på gaden i protest mod Musharrafs proamerikanske politik. Det er de rørende enige om, shiiter, sunnittraditionalister, sunnitiske islamister. Men bortset fra det er de rivaler. Hver gruppe samler tilhængere om sig ved at distancere sig fra de andre og hævde, at deres forståelse af islam og deres religiøse praksis er bedre end de andres, og ved at følge netop dem er tilhængerne nærmere Profetens anvisninger og Guds vilje.

Der findes ingen overordnet religiøs magt med autoritet til at afgøre, hvem af dem, der har ret, men islam er af afgørende betydning for formentlig næsten alle menneskers selvforståelse i Pakistan, bortset fra de ikke-muslimske minoriteter, og derfor er der en intens rivalitet mellem de religiøse ledere om at mobilisere folk. Grupperne kappes om at beherske de store moskeer og indsætte prædikanterne, hvis ord under 
fredagsbønnen kan få store mængder på gaden bagefter med politiske krav.

Ingen politisk leder i Pakistan har råd til at lade konkurrenterne løbe med islam, heller ikke præsident og general Pervez Musharraf. Derfor er han nødt til at give de religiøse noget til gengæld for sin alliance med USA og sin forståelse med Indien.

\section{Autonome stammefolk}

Således bliver religionen dybt politiseret og politikken dybt præget af religion, og det principielle skel mellem etniske og religiøse konflikter sløres.

Det ses også af de tilbagevendende kampe i de såkaldte føderalt administrerede stammeområder (FATA), der ligger som et bælte op mod den afghanske grænse og er befolket med pashtuner ligesom ovre på den anden side.

Områderne er inddelt i tribal agencies og styres efter egne traditioner og af egne ledere, de står ikke under pakistansk lov og jurisdiktion, den pakistanske ordensmagt må kun være til stede i begrænset omfang og efter aftale, og regeringen repræsenteres over for stammernes ledere af befuldmægtigede kommissærer, et system som går tilbage til de britiske koloniherrers tid før 1947.

Tidligere konflikter mellem Islamabad og stammefolkene har mest drejet sig om ikke-religiøse spørgs- mål som størrelsen af subsidier fra regeringen og selvstyrets omfang. Men i 1994 kom der en opstand, hvis mål var at få gældende ret erstattet med islamisk lov, og siden er de traditionelle modsætninger blevet mere og mere infiltreret af religion. Siden Musharrafs alliance med Bush 2001 har stammerne givet ly til talebaner på flugt fra amerikanske styrker i Afghanistan.

Og når så USA fik overtalt Musharraf til at sende sit militær ind i stammelandet for at fjerne de militante islamister, mødte det hård væbnet modstand fra stammernes militser, samtidig med at de religiøse partier i selve Pakistan udnyttede situationen til at mobilisere den religiøse opinion mod præsidenten og hans alliance med islams fjender.

I Sydwaziristan indgik militæret og stammerne efter længere tids kampe en aftale sidste år i februar, i Nordwaziristan skete noget lignende i begyndelsen af september i år, i Bajaur er situationen nu flydende, efter at regeringens raketter udslettede en koranskole nær Khar den 30. oktober, muligvis for at hindre en aftale mellem hæren og stammelederne dér.

Hvad der egentlig foregår, er ret ugennemskueligt. Men hæren skal have sat 80.000 mand ind mod militserne. Alligevel har de efterfølgende aftaler med stammelederne stort set fastholdt status quo, så hvor målrettet har regeringens indsats egentlig været mod stammernes autonomi i 
grænselandet og mod den religiøse ekstremisme?

Måske har Musharraf for balancens skyld givet lidt med den ene hånd til det internationale samfund og lidt med den anden til de hjemlige religiøse ledere.

\section{Mellem klientelle grupper}

Men det er også muligt, at de religiøse ledere giver Musharraf noget for noget. Alliancen af seks religiøse partier i Muttahid Majles-i-Amal er med til at give ham en vis parlamentarisk dækning. Til gengæld får de lov at operere så nogenlunde uhindret. Også de kan være under pres fra flere sider - mellem magten og tilhængernes forventninger.

Politisk, socialt og økonomisk ambitiøse familier skal have medlemmer placeret nær alle samfundets magtcentrer. Et medlem godt placeret i hæren, et i bureaukratiet, et i politiet, et i hvert af de vigtigste politiske partier, så er familien som helhed dækket ind uanset militærstyre, parlamentarisk demokrati eller en hybrid mellem begge dele, så brydes forbindelsen til magten ikke, selv om der skulle komme et uventet regimeskift.

Familie skal her forstås meget bredt. En betydningsfuld familie er $\emptyset$ verste led i et vidtforgrenet net af klienter og klienters klienter. Jo større og mere omfattende, jo mere indflydelse. Men indflydelsen forudsætter, at familien er i stand til at gøre noget for medlemmer og klienter. Det kan den kun, når den er med inde, hvor beslutninger træffes og goder fordeles. Derfor må den sørge for, at forbindelsen til magtens kilder aldrig sander til.

Mindre grupper samarbejder om fælles interesser og om at modarbejde rivaliserende interesser ved at indordne sig i større fællesskaber under den dominerende familie. I hver enkelt gruppe får medlemmerne social og økonomisk støtte og også beskyttelse af gruppens overhoved.

Det kan overhovedet give på grund af sine forbindelser opad i systemet, for de højere skylder de lavere noget til gengæld for den støtte, de lavere skaffer de højere ved at underordne sig og samarbejde med dem og ikke med deres rivaler. Men det forudsætter gruppelederens kontrol med medlemmerne. Til gengæld opnår han gevinster, han kan belønne medlemmerne med. Derved opretholder han også sin egen stilling i forhold til dem. Men afgørende er, at de øverste og dominerende familier har adgang til omfattende goder og ressourcer, som de kan lade sive ned langs de klientelle kæder til gengæld for støtte og opbakning. Og den adgang har de ikke uden forbindelse til magten.

Hvem er ude, og hvem er inde, når beslutningerne træffes, det er afgørende i dette magtfordelingssystem - braderi kaldes det, broderskab eller broderlig hjælp på punjabi. 
Tilsvarende kan magten ikke undvære, at væsentlige grupper samarbejder med den. Jo mere vidtspændende, jo mere indflydelsesrige, jo vigtigere interesser de repræsenterer, jo nyttigere vil de være for magten, jo bedre forhandlingsposition vil de få. I det lys kan man se forholdet mellem Pakistans regering og de politiske partier, herunder de religiøse. Partierne er interessegrupper, der kan handle med regeringen og få indflydelse, hvis de har noget at byde på, eller hvis de kan skabe så store problemer, at det er en fordel at købe deres samarbejde.

Deres magt beror ikke blot på, hvor mange stemmer de kan mønstre ved valgene, eller i hvor mange de kan få på gaden og demonstrere, men også på hvilke klientelle grupper, de kan alliere sig med for at opnå indflydelse i den givne situation.
Men her er partierne ikke de eneste interessegrupper, som er i spil. Alliancerne kommer og går, og partierne risikerer at spaltes: Kan lederen ikke skabe eller udnytte en forhandlingsposition, søger gruppen én, der kan gøre det bedre, eller magten kan stille en ny leder fordele i udsigt, som man ikke vil give den hidtidige.

Det er i dette komplicerede og labile politiske spil, Pakistans præsident må manøvrere. Det er det, der sætter rammen, når han skal balancere mellem krav og pres fra mange sider.

Mogens Fenger er cand. mag. $i$ historie og har mange ophold $i$ Subkontinentet bag sig 